$12-1-2004$

\title{
More Borrowing from Bellegarde in Delarivier Manley's Queen Zarah and the Zarazians
}

Rachel Carnell

Cleveland State University, r.carnell@csuohio.edu

Follow this and additional works at: https://engagedscholarship.csuohio.edu/cleng_facpub

Part of the English Language and Literature Commons

How does access to this work benefit you? Let us know!

\section{Publisher's Statement}

This is a pre-copyedited, author-produced PDF of an article accepted for publication in Notes \& Queries following peer review. The version of record "More Borrowing from Bellegarde in Delarivier Manley's Queen Zarah and the Zarazians." Notes and Queries (N\&Q) 2004 Dec; 51 (249) (4): 377-79. is available online at: http://nq.oxfordjournals.org/content/51/4/ 377.full.pdf+html .

\section{Recommended Citation}

Carnell, Rachel, "More Borrowing from Bellegarde in Delarivier Manley's Queen Zarah and the Zarazians" (2004). English Faculty Publications. 1.

https://engagedscholarship.csuohio.edu/cleng_facpub/1

This Article is brought to you for free and open access by the English Department at EngagedScholarship@CSU. It has been accepted for inclusion in English Faculty Publications by an authorized administrator of EngagedScholarship@CSU. For more information, please contact library.es@csuohio.edu. 


\section{MORE BORROWING FROM BELLEGARDE IN DELARIVIER MANLEY'S QUEEN ZARAH AND THE ZARAZIANS}

MANLEY scholars have long been aware that certain passages in Queen Zarah and the Zarazians (1705) are not wholly original. John L. Sutton has established that the preface to Queen Zarah is a literal translation of 'Sur L'Histoire', the second essay or 'letter' in the Abbé Morvan de Bellegarde's Lettres curieuses de littérature et de morale, ${ }^{1}$ which itself is a paraphrase of Sieur du Plaisir's Sentimens sur les lettres et sur l'histoire (1683). ${ }^{2}$ Catherine Gallagher and Ruth Herman have traced Manley's indebtedness to passages in Hattigé: ou les Amours du Roy de Tamaran, Nouvelle (Cologne, 1676). ${ }^{3}$

Another lengthy passage in the second volume of Queen Zarah, which is noticeably unlike the rest of the volume in style and composition, may now also be ascribed to Morvan de Bellegarde. The passage in Queen

1 John L. Sutton, 'The Sources of Mrs. Manley's Preface to Queen Zarah', Modern Philology, lxxxii (1984), 167-72.

${ }^{2}$ Frédéric Deloffre, La Nouvelle en France à l'âge classique (Paris, 1967), 57. Phillipe Hourcade (ed.), Introduction to Sentiments sur les lettres et sur l'histoire avec des scrupules sur le style (Paris, 1975), 2.

${ }^{3}$ Ruth Herman, 'Similarities Between Delarivier Manley's Secrety History of Queen Zarah and the English Translation of Hattigé, $N \& Q$, xlvii (2004), 193-6. Catherine Gallagher, Nobody's Story: The vanishing acts of women writers in the marketplace, 1670-1820 (Oxford, 1994), 103 n. 29.
Zarah begins, 'Tis the Character of an Honest Politician, to contribute as much as he possibly can in order [sic] to the general Content of the World' and ends about thirty pages later with the observation: 'But it is high time, after this long digression, to return to our Story again'. ${ }^{4}$ This 'long digression' is derived from 'Sur le Bon Goût', the first letter, out of five, in Bellegarde's Lettres curieuses. As she did in her Preface, Manley here again translates directly from the 1705 Hague edition of Bellegarde's Lettres, rather than relying on the 1705 English translation.

Manley begins borrowing about two-thirds of the way through Bellegarde's 'Sur le Bon Goût', with the line: 'C'est le caractere d'un honnête homme, \& qui sait vive, de contribuer autant qu'il le peut, à faire en sorte que tout le monde soit content. ${ }^{5}$ When Manley nears the end of Bellegarde's letter, she skips the closing flourishes but starts borrowing again near the beginning, after the opening expressions of politeness, continuing almost to the sentence with which she began (Zarah, 116-32, 'Bon Goût', 8-28). In other words, whether because she was trying to disguise her borrowing from Bellegarde or for some other reason, Manley turns the letter inside out, starting with the final section about an 'honnête homme' or 'honest Politician', as she translates it, then ending with earlier sections of the letter which comment on such topics as how to teach good sense to children and the problem of vanity in the higher ranks.

The change that Manley makes in the first sentence of her borrowed 'digression' from 'honnête homme' to 'honest Politician' indicates a general change in tone that she effects throughout the passage: she adapts Bellegarde's moral (although not necessarily apolitical) analysis of good taste and manners at court into a more overtly political commentary on the appropriate behaviour of a courtier. Within the context of Manley's Queen Zarah, the real-life courtier on whose behaviour this digression must bear is Sarah Churchill, Duchess of Marlborough, who so misunderstands her role as attendant that she has usurped the

\footnotetext{
${ }^{4}$ Delarivier Manley, The Secret History of Queen Zarah and the Zarazians (London, 1705),104, 132.

5 L'Abbé de Bellegarde, Lettres curieuses de Litterature et de morale (la Haye [the Hague], 1702), 30.
} 
position of monarch. Tellingly, rather than translating 'le bon goût' as 'good taste', Manley regularly translates it as 'judgment', a term whose political resonance may be more obvious to her readers. By calling attention to the end of her 'digression' as she 'return[s] to our Story again', Manley encourages the reader to consider how her analysis of courtly behaviour and judgement might apply to a scene in which 'we shall find Hippolito [John Churchill] acting the most Generous thing, and Zarah [Sarah Churchill] the most Niggardly Unfriendly Part in the World' (132). The reader might logically conclude that Sarah Churchill's behaviour is not at all the obligingly appropriate behaviour expected of a loyal courtier. Moreover, Manley's adaptation of Bellegarde's work so as to emphasize its political overtones is consistent with the way that she modified the passages she borrowed from Hattigé in the first volume of Queen Zarah in order to emphasize her political critique of certain 'Ministers of State' and their policies. ${ }^{6}$

Aside from this slight shift in emphasis, Manley's translation is fairly close to the original. She translates sentence by sentence for several pages at a time, covering such topics as raillery, ill humour, coquetry, conceit, moral education, and pleasing conversation. None of the commentary about these topics is new or surprising; however, Manley's strategy may lie in the very predictability of the material. If accused of denigrating the behaviour of certain powerful persons at court, she could beg innocence on the grounds that she was simply repeating commonplace moral platitudes about court life. Citing Bellegarde as a source text might even have provided her a further measure of deniability.

When borrowing from Bellegarde, Manley usually omits paragraphs that provide lengthy examples from ancient history or paragraphs in which Bellegarde addresses the 'Dame de la Cour' to whom the letter is ostensibly directed.

\footnotetext{
${ }^{6}$ See Queen Zarah, 2-3; Herman explains just how Manley adapts Hattigé into a critique of 'party politics' ('Similarities Between', 194-5). See also Ruth Herman, The Business of a Woman: The Political Writings of Delarivier Manley (Newark and London, 2003), 35-65, for a fuller discussion the specific elements of Tory propaganda in Queen Zarah.
}

In making transitions between the different portions, Manley several times provides her own seguë. For example, she replaces a paragraph in which Bellegarde obsequiously flatters his addressee and then launches into a long anecdote about a woman who ate plaster and a man who preferred the noise of frogs to that of birds, with the observation: 'But how hard it is to find a solid Judgment in Women, or indeed to know what it is; either in Men or Women' (115). That Manley should insert from her own pen such a denigrating comment about women might seem surprising for a woman of her own ability and judgement, except that it fits with her overall characterization of Sarah Churchill as cunning, but lacking in moral and political judgment.

Elsewhere, Manley makes a similar insertion of her own into Bellegarde's text, also to do with the character of women. She translates directly at first: 'I know no Reason why the Women shou'd be reproach'd with being mercenary and Coquettish, 'tis a Piece of Injustice done them' (Zarah, 110, 'Bon Goût', 37). Manley then omits most of the following passage in which Bellegarde observes that seventeen centuries ago Juvenal made the same complaint about women:

Il y a dix-sept Siécles que Juvenal faisoit aux Dames Romaines, les mêmes reproches que l'on fait aux Dames de ce temps-ci: Je crois même, que les Modernes ont encore plus de retenuë. Si l'on remonte dans les siécles plus reculez, on trouvera les mêmes foibles, les mêmes attachements, le même penchant dans les deux sexes; ainsi c'est une phrase usée de dire, que les Dames n'ont jamais été si libertines; \& que le vice n's jamais paru avec tant de licence. (37)

Rather than referring to Juvenal or other ages past, Manley interjects in the voice of her own narrative persona, 'I think they [women] should be so [mercenary and coquettish], and at all things make use of their Charms to please Men'. She completes her sentence with Bellegarde's observation that 'we may find the same Desires in both Sexes' (110), but omits his final point about how hackneyed it is to assert that women have never been so libertine, or licentious as they are today. Although modern readers might cringe at this 
pre-feminist perception of women's obligation to 'please Men', these lines from Manley's own pen are, like the previous ones, consistent with Manley's political strategy of laying the blame for the Whig control of Anne's Ministry on the figure of Queen Zarah, who is, as Ruth Herman points out, not merely Sarah Churchill, the woman, but a 'symbol of corrupt Junto authority'.

RACHEL CARNELL

Cleveland State University

${ }^{7}$ Herman, Business of a Woman, 5 洄

Post-print standardized by MSL Academic Endeavors, the imprint of the Michael Schwartz Library at Cleveland State University, 2015 